\title{
$\mathrm{ABO}$ 혈액형 기록 불일치로 적발된 신분 도용 사례
}

최수인 ${ }^{1} \cdot$ 신희봉 $^{2} \cdot$ 조 덕 $^{3}$

순천향대학교 부속 천안병원 진단검사의학과 ${ }^{1}$, 순천향대학교 부속 부천병원 진단검사의학과 ${ }^{2}$, 성균관대학교 의과대학 삼성서울병원 진단검사의학과 ${ }^{3}$

\section{Cases of Medical Identity Theft Recognized by Historical ABO Discrepancies}

\section{Sooin $\mathrm{Choi}^{1}$, Hee Bong Shin ${ }^{2}$, Duck Cho ${ }^{3}$}

Department of Laboratory Medicine, Soonchunhyang University Cheonan Hospital, Soonchunhyang University College of Medicine ${ }^{1}$, Cheonan Department of Laboratory Medicine. Soonchunhyang University Bucheon Hospital, Soonchunhyang University College of Medicine ${ }^{2}$. Bucheon Department of Laboratory Medicine and Genetics, Samsung Medical Center, Sungkyunkwan University School of Medicine ${ }^{3}$, Seoul, Korea

$\mathrm{ABO}$ 혈액형 불일치에 의한 수혈사고 예방은 수혈을 실시하는 모든 의료기관에서 매우 중요하 다. 이를 위한 첫 단계는 정확한 환자 확인 후 채 혈이다. 하지만, 의료진이 이러한 환자 확인에 주 의를 기울여도 다른 환자의 혈액을 실수로 채혈 할 경우는 발생할 수 있으므로 Cho 등[1]은 이를 예방하기 위해 $\mathrm{ABO}$ 혈액형 검사 용 검체와 교차 시험 용 검체를 분리하여 두 번의 채혈을 요구하 는 정책을 실시해야 함을 강조하였다. 그런데, 이 러한 정책은 $\mathrm{ABO}$ 혈액형 결과의 과거 기록이 없 는 환자에 해당되며, 기록이 확인되는 경우는 한 번 채혈한 검체로 교차시험 후 수혈하는 정책이 대부분이다. 수혈을 필요로 하는 혈액종양환자가 동일 의료기관을 방문할 경우가 이러한 대표적인 사례이다. 그런데, 최근 해외에서 의료진의 환자 확인 실수가 아닌 의료보험증 도용 등과 같은 원
인에 의한 $\mathrm{ABO}$ 혈액형 검사 기록 불일치 사례가 보고되었다[2]. 국내에서도 이러한 사례가 있어 왔으나 그간 학술지에 보고된 바가 없었다. 이에 저자들은 수혈전검사에서 과거와 다른 $\mathrm{ABO}$ 혈 액형이 확인되어 적발된 신분 도용의 증례를 문 헌고찰과 함께 보고하는 바이다.

\section{증례 1}

45세 남자 환자가 내원 3일 전 시작된 무릎통증 을 주소로 $\mathrm{A}$ 병원 응급실에 내원하였다. 특이병력 없는 환자로 화농성 관절염 의증 하에 입원하여 시 행한 $\mathrm{ABO}$ 혈액형 검사에서 $\mathrm{AB}$ 형이었다(SIHDIA anti-A, -B and -D, 신양화학약품, 시흥, 한국; Affirmagen A1 and B cells, Ortho-Clinical Diagnostics, Raritan, NJ, USA). 내원 1년반 전에 시행했던 과거 $\mathrm{ABO}$ 혈액형검사 결과에서는 환자의 혈액형이 $\mathrm{B}$ 형

Received on March 21, 2019. Revised on April 4, 2019. Accepted on April 15, 2019

Correspondence to: Sooin Choi

Department of Laboratory Medicine, Soonchunhyang University Cheonan Hospital, Soonchunhyang University College of Medicine, 31 Suncheonhyang 6-gil, Dongnam-gu, Cheonan 31151, Korea

Tel: 82-41-570-3561, Fax: 82-41-572-2316, E-mail: applesuin@gmail.com, ORCID: http://orcid.org/0000-0003-4746-4809

(a) This is an Open Access article distributed under the terms of the Creative Commons Attribution Non-Commercial License (http://creativecommons.org/licenses/by-nc/4.0) which permits unrestricted non-commercial use, distribution, and reproduction in any medium, provided the original work is properly cited.

Copyright (C) 2019 The Korean Society of Blood Transfusion 
이었다. 재채혈하여 시행한 검사결과는 $\mathrm{AB}$ 형이었 다. 환자는 본인의 혈액형을 $\mathrm{AB}$ 형으로 알고 있었으 며, 골수이식 등의 과거력은 없었다. 환자를 설득하 여 타인의 환자번호를 도용하였음을 확인하였다.

\section{증례 2}

33세 남자 환자가 건강검진을 위해 $\mathrm{B}$ 병원에 내 원하였다. 특이 병력이 없는 분으로 당시 시행한 $\mathrm{ABO}$ 혈액형 검사에서 $\mathrm{AB}$ 형이었다(Anti-A, Anti-B, Affirmagen A1 and B cells, Ortho-Clinical Diagnostics, Raritan, NJ, USA). 하지만 내원 5 개월 전에 시행 한 검사결과는 A형이었다. 재채혈 하여 시행한 검사결과 역시 $\mathrm{AB}$ 형이었다. 외국 국적을 가진 형 이 5 개월 전에 환자의 의료보험증을 사용하여 진 료와 검사를 실시하였음을 확인하였다.

일반적으로 추천되는 환자확인 방법은 진료순 서표, 진료카드 및 환자인식팔찌 등의 서류로 환 자 이름과 등록번호를 확인하고, 더불어 개방형 질문으로 환자의 이름을 묻는 것이다. 하지만 이 러한 확인방법은 환자가 신분을 거짓으로 제시할 경우 이를 확인할 수 없다는 단점이 있다. 일반적 으로 환자가 내원하여 시행하는 검사 중 혈액형 검사는 골수이식 등과 같은 상황을 제외하고 변 경되지 않기 때문에, 과거 결과와의 불일치가 발 견되는 경우 검사전 과정이나 검사과정에서의 오
류 또는 신분 도용을 강력하게 의심하는 근거가 된다. Table 1에 이번 증례들과 함께 문헌으로 보 고된 수혈전검사 결과의 불일치로 인해 발견된 신분 도용에 대해 정리하였다. 기존 문헌보고에 서는 $\mathrm{ABO}$ 혈액형뿐만 아니라, 수혈력이나 임신 력 등 적혈구항원에 노출될 가능성이 없음에도 불구하고 비예기항체가 발생한 원인을 설명할 수 있는 하나의 가능성으로 신분 도용을 제시한 바 있다[2,3]. 만약 환자의 과거 비예기항체 검사결 과와의 불일치를 $\mathrm{ABO}$ 불일치와 함께 신분 도용 의 표식으로 사용한다면 국내에서도 신분 도용이 추가로 발견될 가능성이 있다.

우리 국민은 국민건강보험법에 의해 의료급여 수급자 및 의료보호대상자를 제외한 모든 이가 가입자 또는 피부양자로서 건강보험이 적용된다. 이러한 건강보험 혜택을 받기 위해 국적 상실, 이 민출국, 주민등록 말소 등의 부적격자가 타인의 건강보험증을 대여 및 도용하여 부정수급 받는 경우는 2017년에 연간 1,391건, 2018년 8월 기준 743건에 이르렀다[4]. 건강보험증 도용은 가족 등 의 친척 및 지인을 통해 이루어지기 때문에, 명의 를 빌려준 쪽에서 자진신고를 하지 않는다면 적 발이 쉽지 않다. 그런데, 저자들은 실제 자진 신 고한 사례를 경험하였는데, 이는 외국인 노동자 가 고용주의 의료보험을 사용하여 수 차례 경한

Table 1. Reported cases of medical identity theft with historical discrepancies of pretransfusion tests

\begin{tabular}{lcccccc}
$\begin{array}{c}\text { Case } \\
\text { No. }\end{array}$ & Age/sex & Test & $\begin{array}{c}\text { Interval between } \\
\text { past and current tests }\end{array}$ & Past result & $\begin{array}{c}\text { Current } \\
\text { result }\end{array}$ & Reference \\
\hline 1 & 33/Female & ABO type & NA & A & O & Mulvey et al. [2] \\
& & Unexpected Ab & NA & Anti-E, -K, -Fy , and -Cw Negative & \\
2 & NA & Unexpected Ab & 1 week & Negative & Anti-K Jator and Hughley [3] \\
3 & 45/Male & ABO type & 1.5 years & B & AB & Present case \\
4 & 33/Male & ABO type & 5 months & A & AB & \\
\hline
\end{tabular}

Abbreviations: NA, not available; Unexpected $\mathrm{Ab}$, unexpected antibody. 
질환으로 진료를 받을 때에는 적발되지 않았다가 수술 및 수혈이 필요한 상황이 발생되자 고용주 가 스스로 자백한 사례였다. 하지만 과거 $\mathrm{ABO}$ 혈 액형 기록 불일치가 확인된 사례가 아니라 본 연 구에 증례로 추가하지는 않았다(unpublished data).

의료기관에서의 신분 도용은 진료비용이 피도 용자에게 직접 청구되지 않기 때문에 피해를 자 각하기 어려우나, 실은 피도용자 및 도용자 모두 에게 위험하다. 타인의 혈액형, 약물알러지 또는 과거력 등의 병력 왜곡으로 인해 치료방법에 영 향을 미칠 수 있기 때문이다. 실제로 외국의 한 조사에서 피도용자의 $28 \%$ 가 도용자에서 유래된 의무기록으로 인해 새로운 질병이 발생하였을 때 오진되거나 부정확한 치료를 받은 것으로 나타났 다[5]. 또한 향후 피도용자의 보험 가입이 거절될 수 있다. 의료기관도 피해를 입는다. 불일치 결과 의 원인을 파악하기 위하여 검사실에서는 재채 혈, 재검을 위한 인력, 시약 및 소모품의 손실을 보았을 뿐만 아니라 환자를 다시 내원케 하여 면 담을 진행하였으며, 환자번호 생성 및 의무기록 및 검사결과의 이전 등 병원 차원의 숨은 손실이 발생하였다. 최종적으로는 국민건강보험재정을 악화시키고 보험료 인상을 초래할 수 있다.

신분 도용에 의한 위험을 방지하기 위해 의료기 관에서는 처음 방문한 환자에 대해 사진이 부착된 신분증을 스캔하여 전자의무기록에 업로드 하고, 전자의무기록을 사용하지 않는 기관에서는 신분 증 사본을 보관하는 등의 방안을 제안하고자 한 다. 내원일마다 사진이 포함된 신분증을 확인하고, 확인하지 못한 경우 사후 모니터링하는 등의 환자 확인 정책을 변경하고 의료진에 대한 교육을 통하 여 신분 도용의 빈도를 감소시킨 보고가 있으며 [5], 향후에는 홍채, 지문, 장문 그리고 안면윤곽 등의 바이오인식 기술의 도입이 고려될 수도 있을 것이다[3]. 국가적 차원의 대책으로는 국민건강보
험법 중 피도용자 및 도용자에 대한 벌칙 조항의 강화 및 의료기관의 수진자 본인여부확인을 의무 화하는 등의 방법을 검토해 볼 수 있을 것이다. 본 증례와 같이 혈액형검사 결과의 불일치를 통하여 신분 도용을 강력하게 의심하고, 실제 도 용을 확인하는 데 성공한 경우는 전체 신분도용 건 중 매우 적은 수일 것으로 추정된다. 정확한 환자 확인이 진단 및 치료를 위해 필수적인 만큼 의료기관에서는 환자 확인 정책을 강화하여 궁극 적으로 신분 도용을 방지해야 하며, 무엇보다도 의료기관에서의 신분 도용이 치명적인 결과를 초 래할 수 있다는 위험성에 대한 국민들의 인식이 중요할 것으로 생각된다.

\section{References}

1. Cho D, Hyun JW, Ryang DW. Prevention of ABO incompatible blood transfusion: '2-2-2 safe blood transfusion campaign'. Korean Soc Blood Transfus 2013;24:79-81

2. Mulvey JJ, Matnani R, Cushing MM. Historical ABO blood group discrepancy: a blessing in disguise to unravel a medical identity theft. Transfusion 2017;57:1096-7

3. Jator EK, Hughley K. ABO/Rh testing, antibody screening, and biometric technology as tools to combat insurance fraud: an example and discussion. Lab Med 2014;45:e3-7

4. Lee MS. Problem of the collection rate of medical fraud (National Health Insurance Service). https://blog.naver.com/asanpride/221380842794 [Online] (last visited on 8 February 2019)

5. Judson T, Haas M, Lagu T. Medical identity theft: prevention and reconciliation initiatives at Massachusetts General Hospital. Jt Comm J Qual Patient Saf 2014;40:291-5 